\section{Pathophysiology Haemostasis and Thrombosis}

Breddin, H.K. 1

Fareed, J. 56

Hoppensteadt, D. 56

Ikoma, H. 23

Iqbal, O. 56

LaMonte, M.P. 39
Lewis, B.E. 46, 56

McGregor, J.L. 29

Markwardt, F. 15

Nicolaides, A.N. 36

Tobu, M. 56

Walenga, J.M. 9, 46

Subject Index Vol. 32, Suppl. 3, 2002

Acute coronary syndrome 46

Anticoagulant 9, 56

Antithrombin 56

Argatroban 1, 9, 15, 23, 39, 46

Cerebral blood flow 39

- ischemia 39

- thrombosis 23

Chronic arterial occlusion 23

Crescentic glomerular nephritis 29

Direct thrombin inhibitor 23

Hemodialysis in AT-III deficiency 23

Heparin 15

- antibody 46

Heparin-induced thrombocytopenia 1

Hirudin 1, 15, 36

Hirulog 1
Inogatran 1

Melagatran 1

Non-reversible inhibitor 56

PEG-hirudin 1

Protease-activated receptor 29

Renal inflammation 29

Reversible inhibitor 56

Stroke 39

Synthetic inhibitors 15

Thrombin 39

- inhibition 29

- inhibitors 1,9,15,46

- - direct 36

Thrombin-receptor-activated protease 29

Thrombosis 56

\title{
KARGER
}

(c) 2002 S. Karger AG, Basel

Fax + 41613061234 